\title{
Ethnozoology of the ritual and magic of the To Bada Ethnic Group in the Lore Lindu Biosphere Reserve, Central Sulawesi, Indonesia
}

\author{
ENY YUNIATI ${ }^{1,2, \boldsymbol{v}}$, SERAFINAH INDRIYANI ${ }^{1}$, JATI BATORO $^{1}$, Y. PURWANTO $^{3}$ \\ ${ }^{1}$ Department of Biology, Faculty of Mathematics and Natural sciences. Universitas Brawijaya. Jl. Veteran, Malang 65145, East Java, Indonesia \\ ${ }^{2}$ Department of Biology, Faculty of Mathematics and Natural sciences, Universitas Tadulako. Jl. Soekarno Hatta Km. 9, Central Sulawesi, \\ Indonesia. Tel.: +62-451-422611, Fax.: +62-451-422844, "email : enybiountad16@yahoo.com \\ ${ }^{3}$ Laboratory of Ethnobotany, Division of Botany, Research Center for Biology, Indonesian Institute of Sciences. Jl. Ir. H. Juanda No. 18, Bogor 16122, \\ West Java, Indonesia
}

Manuscript received: 7 March 2020. Revision accepted: 18 May 2020

\begin{abstract}
Yuniati E, Indriyani S, Batoro J, Purwanto Y. 2020. Ethnozoology of the ritual and magic of the To Bada Ethnic Group in the Lore Lindu Biosphere Reserve, Central Sulawesi, Indonesia. Biodiversitas 21: 2645-2653. The To Bada are a traditional ethnic group or community that lives in the Bada valley in the Lore Lindu biosphere reserve. In some spheres, the Bada people still maintain traditional values and principles. This study aims to identify the animals used in rituals, magical and traditional activities among the Bada people, to investigate the ethnozoological perceptions and conceptions that are influenced by social and cultural factors, and to determine animal conservation status. The research method used was a participatory exploration survey with in-depth, open-ended, and semi-structured interviews. The results demonstrate that animal parts used in rituals and various traditions include eggs, heads, horns, blood, flesh, and the whole body. In addition, some body parts and product animals are believed to have magical value, such as fur, sound, and the whole body. The animals used most in rituals are the buffalo, cow, pig, free-range chicken, and partridge. Animals that have magical value are birds and mammals.
\end{abstract}

Keywords: Ethnozoology, magical, ritual, To Bada

\section{INTRODUCTION}

Indonesia is an archipelagic country that has high cultural diversity and wide biodiversity. Indonesia consists of approximately 370 ethnic groups (Ministry of Environment and Forestry of Indonesia 2014; Rintelen et al. 2017). High cultural diversity produces local knowledge that is integrated with customs and traditions and reflected in the shape of the house, arts, health, and clothing (Pusat Data dan Statistik Pendidikan dan Kebudayaan 2016). Local wisdom is the knowledge possessed by indigenous peoples and the noble values in the life of community order, such as the management and utilization of natural resources (BAPPENAS 2012).

Nature provides useful resources for humans: flora and fauna have been widely used since the early period of human history. The relationship between humans and nature can be identified from such sources as ancient paintings on cave walls, such as the paintings of bison, deer, and horses being hunted by humans (Alves 2012). In Sulawesi, there are cave paintings that depict buffalo being hunted by humans. This painting is estimated to be 40,000 years old (Kholis 2017). Flora and fauna are used to meet the needs and support the activities of humans. Animal resources are used for food, clothing, jewelry, equipment, decoration, medicine, and to provide spiritual objects that have magical value (Alves 2012). Humans use animals based on the local knowledge they have, which is passed down through the generations (Alves and Souto 2015). Local knowledge is an essential part of cultural heritage that can reflect the relationship of the past to the present, and between traditional communities and nature (Alves et al. 2013).

Such local knowledge encompasses ethnozoology, which is part of ethnobiology (Hunn 2011). It is a multidisciplinary science that studies local knowledge of animals and humans, such as nomenclature, classification, and beliefs. Ethnozoology is crucial for conservation (Drumond et al. 2015), biodiversity information, assisting strategies in evaluating the impact of human culture on animal species, and developing strategic plans for sustainable development management (Alves and Souto 2015; Bonifacio et al. 2016). Magically valuable animals have positive and negative meanings for conservation (Drumond et al. 2015). Conservationists must treat magical animals more seriously because they can have positive and negative impacts on many species and ecosystems (Holmes et al. 2018). Humans find animals interesting and useful, and an assumption can be made that certain individuals' or communities' lives depend on animals (Yenmis et al. 2018). The focus of ethnozoology is on the relationship between humans and animals. Humans become part of the discussion as their lives are related to and dependent on animals in many ways. Furthermore, ethnozoology studies this relationship in the context of the local culture and the social environment (Verma et al. 2014; Pilatus 2017). As time goes by, it is feared that local knowledge will be lost and undocumented, making it challenging to know how particular ethnic groups use animals. Ethnozoology also has a significant role in conservation (Farida et al. 2014). 
There are 15 ethnic groups in Central Sulawesi, with 24 languages and different socio-cultural backgrounds. Some of these ethnic groups live in the highlands (Suryanto et al. 2013), where they have an abundance of natural resources. Traditional knowledge developed in the community can process, utilize, and conserve the natural resources in the area. The socio-cultural background of traditional society produces unique forms of local wisdom. Local wisdom is the outlook and life strategy in the activities of a local community (Permana 2010; Pusat Data dan Statistik Pendidikan dan Kebudayaan 2016). One example of local wisdom, among others, concerns the traditional activities, rituals, and beliefs surrounding magical things. Traditional societies still carry out rituals and believe in myths in special ways, and these factors have an impact on the development and conservation of natural resources (Sartini and Effendhy 2012). Magic is something that is believed to be able to give rise to special powers and be able to dominate the human mind (Anwar 2018). Magically valuable animals are dynamic and have become part of human cultural heritage (Holmes et al. 2018). Humans as hunters are very dependent on nature. That is when people are familiar with the traditions of farming systems and can utilize the natural resources of the surrounding environment (Rim 2014).

The ethnic Bada is an indigenous community that lives in the Bada valley. They live in the buffer zones in the Lore Lindu biosphere reserve in Poso, Central Sulawesi Province, Indonesia, and still adhere to customary law (To Bada). UNESCO established the Lore Lindu biosphere reserve in 1977 (Khaeruddin 2019). The Lore Lindu biosphere reserve consists of three zones, namely: the core zone (Lore Lindu National Park), covering an area of 217,991.9 ha located in Poso and Sigi Regencies; the buffer zone, covering an area of 503,738 ha located in the cities of Palu, Sigi Regency, and Poso Regency; and the transition zone, covering an area of 1,461,263 ha located in the districts of Donggala, Sigi, Poso, Parigi Moutong, and the city of Palu (Munawaroh et al. 2013). They utilize natural resources in the forest to fulfill their needs and support their daily activities. The To Bada is an agrarian community, the majority of whom are farmers who use paddy fields and gardens to generate income and use the forest as an additional resource. The To Bada community also raises livestock, such as cows, pigs, buffaloes, chickens, and freshwater fish, such as goldfish, tilapia, and parrotfish. The Bada valley consists of two districts, namely West Lore and South Lore, which are located at an altitude of 760-1.060 MASL (Munawaroh et al. 2013). There are two rivers, the Lariang and Malei. The Bada Valley was designated a cultural heritage area following the discovery of megalithic statues (Mashuri 2011). In their daily lives, Bada people still practice traditional activities and believe in magic. The Bada people cannot be separated from their animals, which they depend upon to support their activities and needs. Considering the rapid development of modern life nowadays, the Bada community an interesting topic for study as it still maintains traditional values. This study investigates their use of animals in their rituals magic.

\section{MATERIALS AND METHODS}

\section{Study area}

This study was conducted in the Bada Valley, located in the Lore Lindu biosphere reserve in Poso Regency, Central Sulawesi, Indonesia, coordinates 10 43'05 " LS and 120011 '03 East (Figure 1). The administrative region of the Bada Valley consists of 14 villages. The center of this region is in the Gintu area. The topography of this region consists of plains and hills and it is surrounded by high mountains (BPS POSO 2016). It lies $74 \mathrm{~km}$ from the city of Poso and $150 \mathrm{~km}$ from the southern town of Palu. Lembah Bada has a harmonious cultural attraction to nature (Mashuri 2011).

\section{Procedures}

This research was conducted in a participatory manner using exploratory survey techniques, interviews, and documentation. Exploratory surveys were used to identify and record which animals are used in rituals, and traditional and magical activities. Ethnozoological data were obtained by using open-ended, in-depth, and semi-structured interviews with respondents who had previously been selected by using purposive sampling (Cotton 1996). Furthermore, snowball sampling was employed to obtain key participants that were in line with the objectives of the study to get the most accurate information (Kusumaningrum et al. 2018). The total number of respondents in this study amounted to 48, comprised of 36 men and 12 women. The key respondents numbered 8 , comprising of 6 men and 2 women (Table 1).

\section{Data analysis}

The data obtained, based on the interviews, included both qualitative and quantitative data. Qualitative and quantitative methods were used to analyze the data. The qualitative data covered the kinds of animals used in traditional, ritual, and magical activities, based on sociocultural values among the To Bada. In addition, quantitative data included the number of species and animal parts used in the rituals and traditional activities. The research data were tabulated in the form of a matrix (Table 1).

\section{Conservation status of species}

The international species conservation status was examined based on animal protection IUCN (2019) and Appendix Cites (2019,) while the national conservation status was reviewed based on government regulation (PP) No.P.106/ MENLHK/SETJEN/KUM.1/12/2018.

Table 1. Number of respondents

\begin{tabular}{llc}
\hline $\begin{array}{c}\text { Respondent } \\
\text { characteristics }\end{array}$ & \multicolumn{1}{c}{ Observation category } & Total \\
\hline Sex & Woman & 12 \\
& Men & 36 \\
Age & <25 years old & 4 \\
& 25-60 years old & 32 \\
& $>60$ years old & 12 \\
Education & Not education & 10 \\
\multirow{2}{*}{ Social status } & Graduated to high school & 38 \\
& Ordinary people & 39 \\
& Public figure & 9 \\
\hline
\end{tabular}




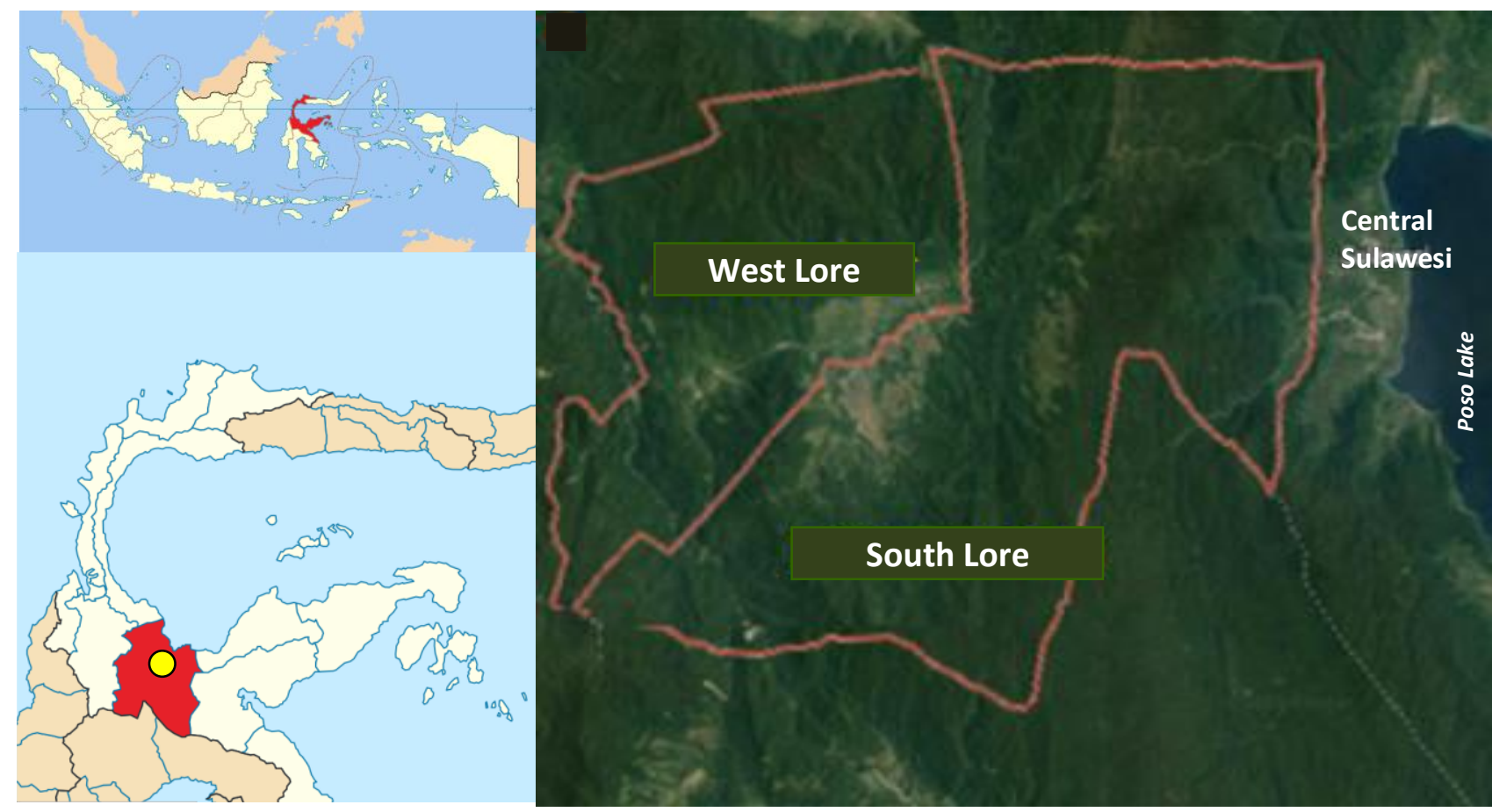

Figure 1. Location of research in Bada Valley, Poso, Central Sulawesi, Indonesia

\section{RESULTS AND DISCUSSION}

\section{Local wisdom of the Bada toward animals}

Bada local wisdom is reflected in their utilization of natural resources. Nature is a space for human social and cultural interaction. In other words, human life cannot be separated from nature and social culture. In Bada knowledge concerning animals, they consider them as social creatures. According to their own narratives of origin, the To Bada originally came from the Baebunta village in South Sulawesi and were led by their ancestor Rawintu, who was accompanied by several dogs. His dogs pursued anoa (Bubalus sp.) to the Bada valley. Consequently, dogs are considered to be an important social creature that is loyal to humans. The male respondents were more knowledgeable about the use of animals in rituals and magic. Men are more likely to work as hunters, while women tend to take care of the house and yard. Commonly, people aged 25-60 are more knowledgeable about the use of animals in rituals and magic. The youth understand less about this.

\section{Biodiversity of animals used in rituals}

Based on the results, there are six species and one subspecies that are commonly used in traditional activities or rituals that are believed to have magical values. These are the throat-spine gudgeon (Belobranchus belobranchus), water buffalo (Bubalus bubalis), cattle (Bos taurus), pig (Sus scrofa), red junglefowl (Gallus), chicken (Gallus gallus domesticus), and horse (Equus caballus) (Figure 2, Table 2). The animal parts used in the ritual are the head, horns, blood, feathers, flesh, tail fur, and the whole body.
The ethnic Bada raises chickens, buffaloes, cattle, and pigs. They use livestock manure to fertilize their garden plants. Livestock is useful in daily life as a source of food, for moving heavy agricultural equipment in the fields, and for rituals and traditional medicine. Animals are used in rituals and customs as symbols and food offerings. The use of animals as traditional symbols can be seen in the form of clothing accessories, decorations, and food. The animals, both domesticated and wild, are obtained from the Bada valley area. In general, those used with traditional agricultural equipment and in ritual activities are domestic animals (Alves et al. 2012). Animal breeds commonly used are pig ( $S$. scrofa), water buffalo (B. bubalis), chicken $(G$. gallus domesticus), and cattle (B. taurus), while the wild animals used are red junglefowl ( $G$. gallus) and throatspine gudgeon (B. belobranchus).

\section{Biodiversity of animals with magical values}

The ethnic Bada (To Bada) still believe in the magical value of animals. Alves et al. (2012) explain that the knowledge of local people about magic is formed through natural relations. In the life of the To Bada, forests are an important part of social culture. People who live in forest areas have magical beliefs based on their respective cultures. According to this study, there are 19 species from the Aves and Mammals classes which are believed by the Bada people to have magical value and power (Table 2). They believe that animals are the sign of a natural event. This can be realized through animal sounds or their presence, especially of certain animals, such as birds, cats, or dogs. Birds which are commonly believed to be natural signs are collared kingfisher (Halcyon chloris), whooper 
swan (Cygnus cygnus), great egret (Egretta alba), little egret (Egretta garzetta), knobbed hornbill (Rhyticeros cassidix), rock dove (Columba livia), spotted dove (Streptopelia chinensis), slender-billed crow (Corvus enca), piping crow (Corvus typicus), black-billed koel (Eudynamys melanorhyncha), sulawesi cuckoo (Cuculus crassirostris), black-faced munia (Lonchura molucca), spotted kestrel (Falco moluccensis), Sulawesi scops owl (Otus manadensis) and brown hawk-owl (Ninox scutulata).

\section{The use of parts and products animal}

Figure 4 shows the attributes of animals that are used or appreciated in this culture. Sound is the most used compared to others; horn, blood, and eggs are the least. Animal sounds are used to identify hazards, such as disasters and death. To Bada uses animals directly and indirectly. Direct utilization includes symbolic use, appreciation of values, use in art and hobbies, and for producing signs of certain natural phenomena. The indirect use of animals requires processing first: for example, preparation for consumption or the production of traditional medicine. Animals that are believed to have magical powers can be used directly, while animals that are used in ritual customs are included in those included in indirect use. Generally, animals used in ritual customs require processing, as they would make accessories or home decorations, or to be used as food.

The types of animals of whom all the body parts are used are throat-spine gudgeon (B. belobranchus), piping crow (C. typicus), great egret (E. alba), little egret (Egretta garzetta), knobbed hornbill ( $R$. cassidix), rock dove $(C$. livia), spotted dove ( $S$. chinensis), chicken ( $G$. gallus domesticus), water buffalo (B. bubalis), cattle (B. taurus), Tonkean macaque (Macaca tonkeana), black rat (Rattus rattus) and pig ( $S$. scrofa). The animals whose head parts are used in rituals are water buffalo (B. bubalis), cattle ( $B$. taurus) and pig ( $S$. scrofa). The animal's head represents a form of accountability of a husband to his wife. In traditional marriages (Ada Kahamboko), water buffalo (B. bubalis), cattle (B. taurus) and pig (S. scrofa) are used as wedding dowry (Holo Tawine).

The utilization of sound is dominated by the Aves class: namely, collared kingfisher $(H$. chloris), slender-billed crow (C. enca), black-billed koel (E. melanorhyncha), whooper swan (C. cygnus), spotted kestrel ( $F$. moluccensis), Sulawesi cuckoo (C. crassirostris), blackfaced munia (L. molucca), brown hawk-owl (N. scutulata), and Sulawesi scops owl (O. manadensis). While Canis familiaris is used from the class of mammals. Other animal products used in rituals, such as eggs, come from chicken (G. gallus domesticus).
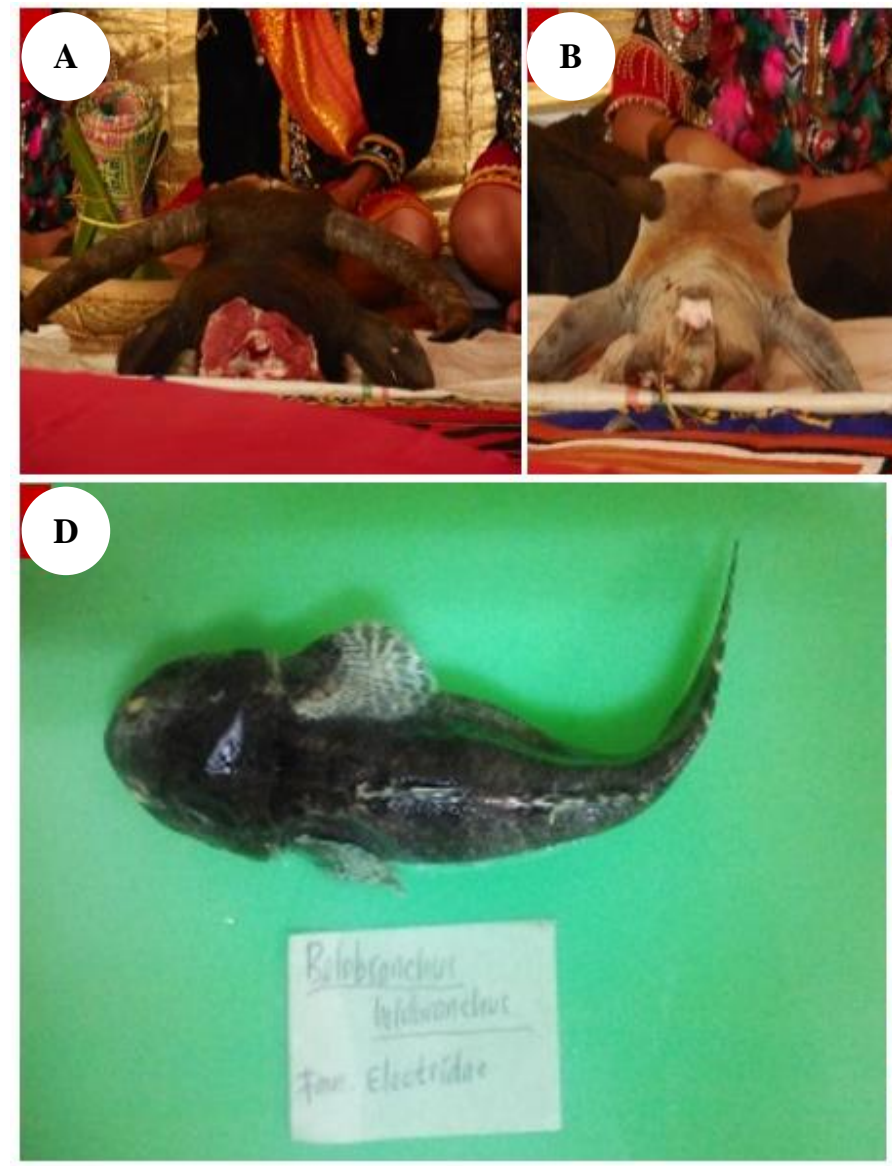
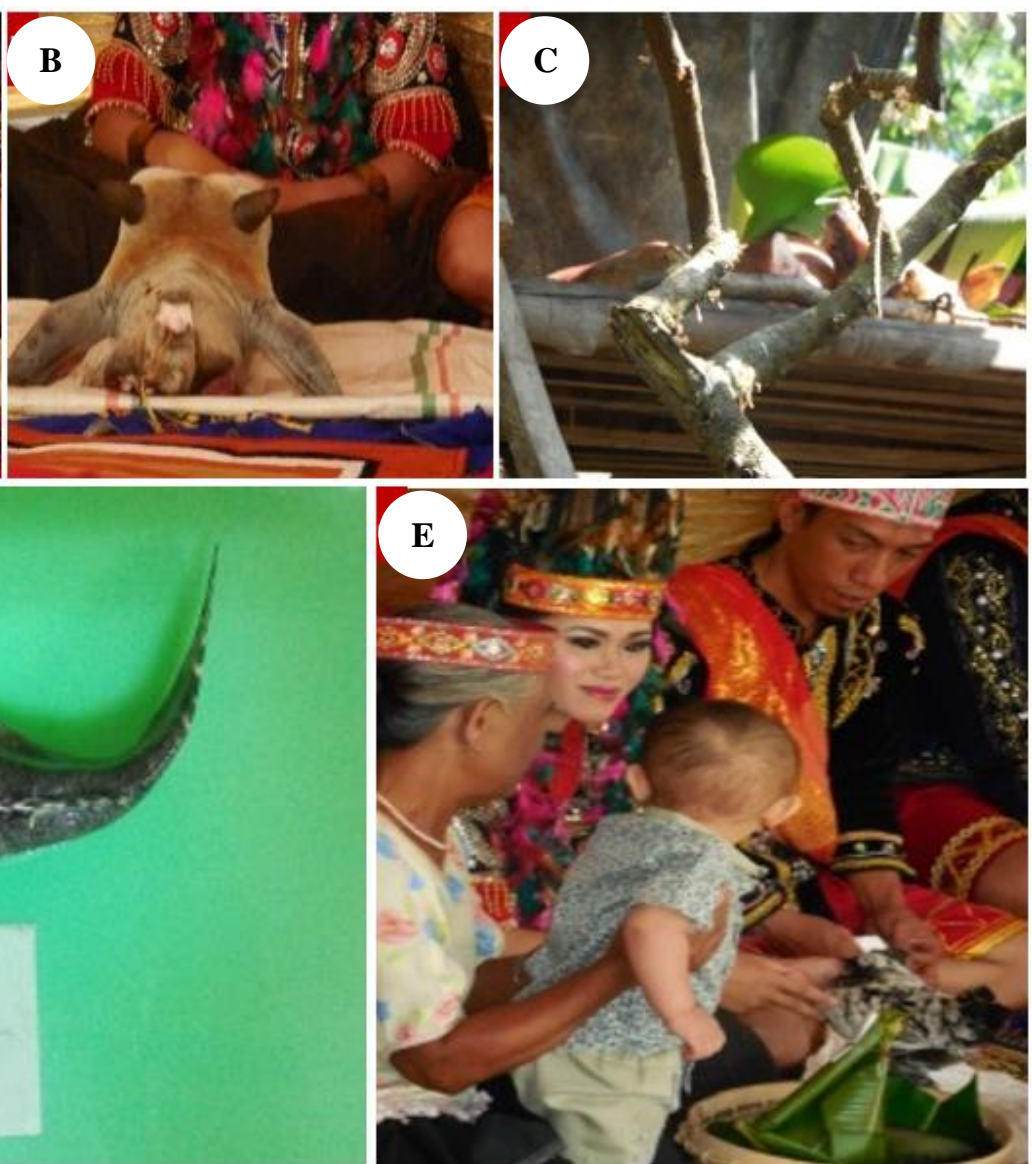

Figures 2. Animals used in rituals. A. Water buffalo (Bubalus bubalis), B. Cattle (Bos taurus), C. Pig (Sus scrofa), D. Throat-spine gudgeon (Belobranchus belobranchus), E. Chicken (Gallus gallus domesticus) 
Table 2. Animals used in rituals and magical activities

\begin{tabular}{|c|c|c|c|c|c|c|c|c|}
\hline \multirow{2}{*}{ Class } & \multirow{2}{*}{ Local name } & \multirow{2}{*}{ Scientific name } & \multirow{2}{*}{ Family } & \multicolumn{2}{|c|}{ Value } & \multicolumn{3}{|c|}{ Conservation status } \\
\hline & & & & Ritual & Magical & IUCN & CITES & PP 106 \\
\hline Actinopterygii & $\begin{array}{l}\text { Bou Ebe } \\
\text { (Throat-spine gudgeon) }\end{array}$ & $\begin{array}{l}\text { Belobranchus belobranchus } \\
\text { (Valenciennes, 1837) }\end{array}$ & Eleotridae & + & - & DD & - & - \\
\hline \multirow[t]{17}{*}{ Aves } & $\begin{array}{l}\text { Tengke } \\
\text { (Collared kingfisher) }\end{array}$ & $\begin{array}{l}\text { Halcyon chloris } \\
\text { (Boddaert, 1783) }\end{array}$ & Alcedinidae & - & + & $\mathrm{LC}$ & - & - \\
\hline & $\begin{array}{l}\text { Banda } \\
\text { (Whooper swan) }\end{array}$ & $\begin{array}{l}\text { Cygnus cygnus } \\
\text { (Linnaeus, } 1758 \text { ) }\end{array}$ & Anatidae & - & + & $\mathrm{LC}$ & - & - \\
\hline & $\begin{array}{l}\text { Timboko baula } \\
\text { (Great egret) }\end{array}$ & $\begin{array}{l}\text { Egretta alba } \\
\text { (Linnaeus, 1758) }\end{array}$ & Ardeidae & - & + & $\mathrm{LC}$ & - & - \\
\hline & $\begin{array}{l}\text { Timboko baula } \\
\text { (Little egret) }\end{array}$ & $\begin{array}{l}\text { Egretta garzetta } \\
\text { (Linnaeus, 1766) }\end{array}$ & & - & + & $\mathrm{LC}$ & - & - \\
\hline & $\begin{array}{l}\text { Alo } \\
\text { (Knobbed hornbill) }\end{array}$ & $\begin{array}{l}\text { Rhyticeros cassidix } \\
\text { Temminck, } 1823\end{array}$ & Bucerotidae & - & + & VU & II & $\sqrt{ }$ \\
\hline & $\begin{array}{l}\text { Bangkebodo } \\
\text { (Rock dove) }\end{array}$ & $\begin{array}{l}\text { Columba livia } \\
\text { Gmelin, } 1789\end{array}$ & Columbidae & - & + & $\mathrm{LC}$ & - & - \\
\hline & $\begin{array}{l}\text { Kokou, woku } \\
\text { (Spotted dove) }\end{array}$ & $\begin{array}{l}\text { Streptopelia chinensis } \\
\text { (Scopoli, 1768) }\end{array}$ & & - & + & - & - & - \\
\hline & $\begin{array}{l}\text { Kaloa } \\
\text { (Slender-billed crow) }\end{array}$ & $\begin{array}{l}\text { Corvus enca } \\
\text { (Horsfield, 1821) }\end{array}$ & Corvidae & - & + & $\mathrm{LC}$ & - & - \\
\hline & $\begin{array}{l}\text { Papalo } \\
\text { (Piping crow) }\end{array}$ & $\begin{array}{l}\text { Corvus typicus } \\
\text { (Bonaparte, 1853) }\end{array}$ & & - & + & $\mathrm{LC}$ & - & $\sqrt{ }$ \\
\hline & $\begin{array}{l}\text { Kureu, Kokolo } \\
\text { (Black-billed koel) }\end{array}$ & $\begin{array}{l}\text { Eudynamys melanorhyncha } \\
\text { S.Muller, } 1843\end{array}$ & Cuculidae & - & + & - & - & - \\
\hline & $\begin{array}{l}\text { Totoku } \\
\text { (Sulawesi cuckoo) }\end{array}$ & $\begin{array}{l}\text { Cuculus crassirostris } \\
\text { (Walden, 1872) }\end{array}$ & & - & + & $\mathrm{LC}$ & - & $\sqrt{ }$ \\
\hline & $\begin{array}{l}\text { Dena } \\
\text { (Black-faced munia) }\end{array}$ & $\begin{array}{l}\text { Lonchura molucca } \\
\text { (Linnaeus, 1766) }\end{array}$ & Estrildidae & - & + & - & - & - \\
\hline & $\begin{array}{l}\text { Tiriu,Kureu } \\
\text { (Spotted kestrel) }\end{array}$ & $\begin{array}{l}\text { Falco moluccensis } \\
\text { (Bonaparte, 1850) }\end{array}$ & Falconidae & - & + & $\mathrm{LC}$ & II & $\sqrt{ }$ \\
\hline & Manu (Chicken) & $\begin{array}{l}\text { Gallus gallus domesticus } \\
\text { (Linnaeus, 1758) }\end{array}$ & Phasianidae & + & - & - & - & - \\
\hline & $\begin{array}{l}\text { Manu kakau } \\
\text { (Red junglefowl) }\end{array}$ & $\begin{array}{l}\text { Gallus gallus } \\
\text { (Linnaeus, 1758) }\end{array}$ & & + & - & $\mathrm{LC}$ & - & - \\
\hline & $\begin{array}{l}\text { Hora } \\
\text { (Brown hawk-owl) }\end{array}$ & $\begin{array}{l}\text { Ninox scutulata } \\
\text { (Raffles, 1822) }\end{array}$ & Strigidae & - & + & $\mathrm{LC}$ & II & - \\
\hline & Hora (Sulawesi scops owl) & $\begin{array}{l}\text { Otus manadensis } \\
\text { (Quoy and Gaimard, 1830) }\end{array}$ & & - & + & $\mathrm{LC}$ & II & $\sqrt{ }$ \\
\hline \multirow[t]{8}{*}{ Mammalia } & $\begin{array}{l}\text { Bouloh } \\
\text { (Water buffalo) }\end{array}$ & $\begin{array}{l}\text { Bubalus bubalis } \\
\text { (Linnaeus, 1758) }\end{array}$ & Bovidae & + & - & - & - & - \\
\hline & Sapi (Cattle) & $\begin{array}{l}\text { Bos taurus } \\
\text { Linnaeus, } 1758\end{array}$ & & + & - & - & - & - \\
\hline & Ahu (Dog) & $\begin{array}{l}\text { Canis familiaris } \\
\text { Linnaeus, } 1758\end{array}$ & Canidae & - & + & - & - & - \\
\hline & $\begin{array}{l}\text { Oba } \\
\text { (Tonkean macaque) }\end{array}$ & $\begin{array}{l}\text { Macaca tonkeana } \\
\text { (Meyer, 1899) }\end{array}$ & Cercopithecidae & - & + & VU & II & $\sqrt{ }$ \\
\hline & Dara (Horse) & $\begin{array}{l}\text { Equus caballus } \\
\text { Linnaeus, } 1758\end{array}$ & Equidae & + & - & - & - & - \\
\hline & Soe (Cat) & $\begin{array}{l}\text { Felis catus } \\
\text { Linnaeus, } 1758\end{array}$ & Felidae & - & + & - & - & - \\
\hline & Tukui (Black rat) & $\begin{array}{l}\text { Rattus rattus } \\
\text { (Linnaeus, } 1758 \text { ) }\end{array}$ & Muridae & - & + & $\mathrm{LC}$ & - & - \\
\hline & Boe (Pig) & $\begin{array}{l}\text { Sus scrofa } \\
\text { Linnaeus, } 1758\end{array}$ & Suidae & + & - & $\mathrm{LC}$ & - & - \\
\hline
\end{tabular}

Note : Conservation international the based on IUCN Red List (DD = Data deficient, LC = Least concern, VU = Vulnerable), and Apendik II CITES, conservation national the based on PP 20 RI, - : Not listed, + : Listed 


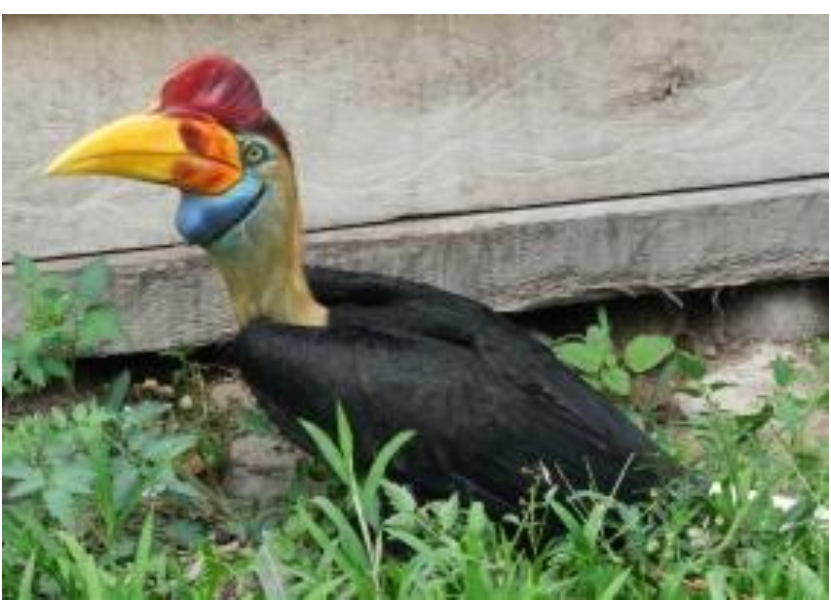

Figure 3. Rhyticeros cassidix as a magical animal

\section{Conservation status of the animal}

Based on research data on the status of conservation arising from the International Union for the Conservation of Nature and Natural Resources (IUCN Redlist), throatspine gudgeon (B. belobranchus) has a DD (Data deficient) status, which means that information is lacking. The conservation status of knobbed hornbill ( $R$. cassidix) and tonkean macaque (M. tonkeana) is VU (Vulnerable), which means they are vulnerable to future extinction if conservation is not carried out. These animals are also included in category II of CITES (Convention on International Trade in Endangered Species of Wild Fauna and Flora) and are at risk of extinction if trade continues without monitoring. Table 2 shows some animals that have LC (Least concern) conservation status, which means there is a low risk of extinction. In several animals that can be eaten, like whooper swan (C. cygnus), great egret (E. alba), little egret (E. garzetta), knobbed hornbill ( $R$. cassidix), rock dove ( $C$. livia), spotted dove ( $S$. chinensis), brown hawk-owl ( $N$. scutulata), Sulawesi scops owl (O. manadensis), and spotted kestrel ( $F$. moluccensis). The use of animals for human needs must be guided by their conservation status granted by the IUCN and, with good management, it is expected a balance will continue between this and the requirements of the local cultures expressed by the local ethnic groups (Alves and Souto 2015). Some animals are included in the category of protected animals based on Government Regulation (PP) No. P. 106/MENLHK/SETJEN/KUM.1/12/2018: namely, knobbed hornbill ( $R$. cassidix), piping crow (C. typicus), Sulawesi cuckoo (C. crassirostris), spotted kestrel ( $F$. moluccensis), sulawesi scops owl (O. manadensis) and Tonkean macaque (M. tonkeana).

The ethnic Bada live in the Bada valley as an agrarian community that uses paddy fields and gardens. Rice (Oryza sativa L.) and garden products, such as cocoa (Theobroma cacao L.), are grown. They live alongside forests and use non-timber forest products, such as rattan, for additional income. The Bada Valley region is designated as a cultural heritage area because there are megalithic statues. The Bada ethnic community originated from the southern

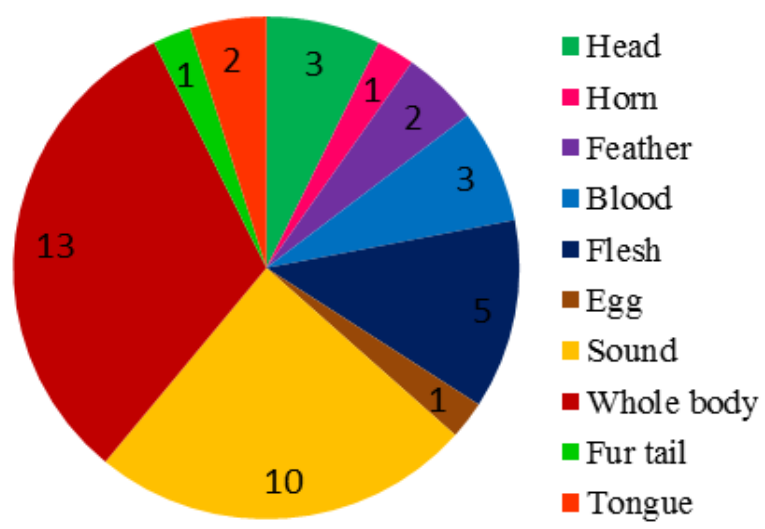

Figure 4. The use of animal parts

Baebunta village of Luwu in South Sulawesi. They migrated through Rampi in South Sulawesi.

The Bada people are an indigenous community (masyarakat adat) who label themselves as the To Bada, and the place they inhabit as Tampo Bada. They maintain several traditional life cycle rituals from birth to death (Ada pousuana katuwo'na tana rungu ra'anaka tuake I kapateana). Various species of animals, such as water buffalo (B. bubalis), cattle (B. taurus), pig (S. scrofa), red junglefowl (G. gallus), and chicken (G. gallus domesticus), are also used in other customs, such as in tributes (Ada pepomahile), livestock salvation (Ada Mowahe boso), the ceremony of placing the first stone when building a house or other buildings (Ada Motulada), land clearing for gardens, ponds and rice fields (Ada Mohia, Mobata'Bonde Hai Mobelai Tampo), and traditional ceremonies to open paddy or irrigation waterways (Ada Manggala Uwai). Horsetail hair (E. caballus) is used in accessories for the piho, a traditional weapon of the To Bada, signifying masculinity and strength. The piho is used in every traditional ritual ceremony. During the buffalo animal rescue ritual (Ada Mowahe boso), it was carried at each event, resulting in the young buffalo being cut as a sign of ownership and survival. In addition, pig's blood was sprinkled around the buffalo cage. In the traditional laying of the first stone of a new building (Ada Motulada) and the opening of new fields (Ada Mohia, Mobata'Bonde Hai Mobelai Tampo) and traditional ceremonies to open paddy or irrigation waterways (Ada Manggala Uwai), pig's, buffalo's and chicken's blood were sprinkled on the land and water channels.

Water buffalo (B. bubalis), cattle (B. taurus), and pig ( $S$. scrofa) are used in weddings, symbolically expressing the husband's responsibility to his wife. As well as being used as sacrifices for purification, they are also offered as dowry from the groom's family to the bride. In addition, these animals are used for customary sanctions (Giwu), if someone transgresses a customary regulation. The Bada people acknowledge social strata in life, including the status of nobles (Tuana), the nobles family or knight (Kabilaha), ordinary people (Tuana Maroa), and the 
descendants of slaves (Hawi). But now the status of Hawi is no longer acknowledged. In customs and rituals, there are differences in the number of animals used in accordance with the strata of the relevant participants.

The eggs of chicken ( $G$. gallus domesticus) are used in offerings, including the plain white egg, which may be presented in odd numbers in offerings, such as five to observe the custom of honor (Ada pepomahile), which means a sacred visit in the Bada valley (Tampo Bada). Odd numbers (5) signify the basic principles of Pancasila and the life of the Indonesian people. The chicken (G. gallus domesticus) is used as an expression of gratitude for the safety of guests who come to the Bada Valley. In addition, in traditional marriages, red junglefowl feathers (G. gallus) are used as head accessories (Hiora), which signify grandeur. Chicken (G. gallus domesticus) and pig ( $S$. scrofa) are used in new land clearing rituals (mohia, mobata 'bonde hai mobelai tampo da nada manggala uwai). Their blood has a meaning of connoting purity and safety. Melayu ethnic use chickens for easy childbirth. Ramadiana (2018) stated that the chickens used as offerings for ghosts, and pigs are animals that can be farmed, and all of their body parts can be used for rituals.

Water buffalo (B. bubalis) is used as part of a bride's wealth dowry in a wedding ceremony and represents the status of ownership. A nobleman (Tuana) will live in a house with a certain style of architecture and which is adorned with horns and buffalo heads. The traditional clothes of the nobles used on ceremonial occasions have buffalo motifs, whereas the ceremonial clothing of nonnobles (kabilaha, tuana maroa and hawi) do not have these motifs and are mostly comprised of just plain colors. House architecture and clothes reflect the social status and identity of a person or family. Buffalos express power, wealth, the source of life, rulership and nobility, and glory. Buffalos are used in everyday life to plow the rice fields; thus it can be said that they provide great support in the economic activities of the Bada community. In other words, the buffalo is a measure of one's dignity and social status. According to Fahlevi et al. (2017), buffalo has a high spiritual value and is used as an important offering in rituals. Not only in the Bada community, the buffalo is also widely used in other customs in other ethnic groups of the region, where their possession also serves as a marker of noble status. The Toraja tribe uses the buffalo in the ceremony of death (Rambu Solo') as a symbol of prosperity and strength, signifying spiritual stature in heaven. Furthermore, buffalo horns are placed in front of houses to mark the social status of the house owner (Ismail 2019).

Knobbed hornbill ( $R$. cassidix) is a species of bird that is believed to be a sign of good luck (Figure 3). Generally, the To Bada use bluebird feathers as accessories around their necks to invite good fortune. When they go hunting in the forest and encounter knobbed hornbill ( $R$. cassidix), the Bada people believe that they will have good luck in their hunting. In the Dayak ethnic group, the head and tail wing feathers are used as traditional ceremonial hat decorations, and the bird is believed to be sacred (Ramadiana et al. 2018). Birds that are believed to be signs of bad things distress, death and danger include slender-billed crow $(C$. enca), black-billed koel (E. melanorhyncha), papalo birds (C. typicus), collared kingfisher (H. chloris), $F$. moluccensis, black-faced munia (L. molucca), and sulawesi cuckoo ( $C$. crassirostris). The sounds of these birds are considered to be a natural signal that something bad is going to happen. If the sound of papalo birds (C. typicus) is heard during the process of development and land clearing, then the process must be stopped. This is because the papalo birds (C. typicus) sound is believed to be a sign of danger to the safety of the property owner. They believe that building edifices or clearing land at that time will not result in good fortune for the owner. In addition, bad things are also believed to occur if these types of birds perch on top of the house. But in the Melayu ethnic group, the sound is believed to signify that someone has given birth (Sukma et al. 2019). The voices of black-faced munia (L. molucca) and spotted kestrel ( $F$. moluccensis) are believed to be a sign of disaster. There is a belief in the Bada community that Sulawesi cuckoo (C. crassirostris) signifies the incarnation of a girl who has been neglected by her parents. Sulawesi cuckoo (C. crassirostris) has such a sad sound that it is considered a sign of inauspicious events. The sound of Sulawesi cuckoo (C. crassirostris), indicates that a nobleman or public figure will die. On the other hand, the sounds of slender-billed crow (C. enca), collared kingfisher (H. chloris), and Sulawesi cuckoo (C. crassirostris) signify the death of ordinary people. Whooper swan (C. cygnus) is believed to cast out evil spirits. Furthermore, rock dove $(C$. livia) and spotted dove (S. chinensis) are types of birds that are kept as pets by the community because it is believed they can invite good luck and happiness, and ward off evil spirits.

The To Bada also believe that certain bird sounds are natural signals telling that there has been a violation of morality, such as adultery in the case of Sulawesi scops owl (O. manadensis) and brown hawk-owl ( $N$. scutulata).They are believed to be a sign of death if they alight near the house at night. Birds which signify time are great egret (E. alba) and little egret (E. garzetta) which, in the morning, fly to the west and in the evening, to the east. The birds that are considered magical and which can be eaten are whooper swan (C. cygnus), great egret (E. alba), little egret (E. garzetta), Knobbed hornbill ( $R$. cassidix), rock dove ( $C$. livia), spotted dove ( $S$. chinensis), brown hawk-owl ( $N$. scutulata), Sulawesi scops owl (O. manadensis), spotted kestrel ( $F$. moluccensis). Considering the protected status of some of these birds, there is a need to institute public education regarding this.

In mammals, Tonkean macaque ( $M$. tonkeana) is considered a bad sign. If someone goes to the forest and encounters $M$. tonkeana, the trip should be stopped. Dog (C. familiaris) and cat (Felis catus) are considered signs of the changing seasons. Dog (C. familiaris) are animals that are loyal to humans, have a good level of alertness, and are considered to be heroes and to be friends in many activities, such as hunting, gardening, and fishing. This is following the early history of the Bada Valley, where Rawintu and his group were accompanied by several dogs, as mentioned earlier. In addition, the sound of $\operatorname{dog}(C$. familiaris) at night is the sign of the presence of spirits. To 
Bada believe that the spirits of the deceased still exist in the vicinity of their relatives. Black rat ( $R$. rattus) is believed to represent the presence of the spirits of families who have died. One form of local wisdom of the Bada community is reflected when they enter the forest, where they will always be accompanied by $\operatorname{dog}(C$. familiaris) as a sign of vigilance. Going to the forest accompanied by dogs is called noasu, which represents the will of the local community and the permission of the leader (Tuana I wanua).

In conclusion, the To Bada is an indigenous community that still adheres to customary law. Their trust in animals and their utilization in magical and ritual contexts could be used as a basis for encouraging the local conservation of animals. Local knowledge functions in the local conservation of animals. To Bada believe that animals that are believed to have magical powers should not be hunted but they can be eaten. The use of animals in rituals is not excessive. If a violation occurs, the transgressor will be fined, with the imposition of sanctions; this is carried out by the adat council. In addition, there is also socialization regarding the importance of conservation of natural resources involving the government and indigenous leaders.

\section{ACKNOWLEDGEMENTS}

The authors wish to thank the Ministry of Research, Technology, and Higher Education of the Republic of Indonesia for funding this research. Also, great appreciation is conveyed to the officials of the Lore Lindu National Park, Central Sulawesi, Indonesia for their participation and support in assisting with this study.

\section{REFERENCES}

Alves RRN and Souto WMS. 2015. Ethnozoology: A brief introduction. Ethnobiol Conserv 4 (1) : 1-13. DOI: 10.15451/ec2015.1-4-1-13.

Alves RRN, Pinto LCL, Barboza RRD, Souto WMS, Oliveira REMCC, Vieira WLS. 2013. A Global overview of carnivores used in traditional medicines. In: Alves RRN and Rosa IL (eds) Animal in Traditional Folk Medicine Implications For Conservation. Springer, Berlin.

Alves RRN, Rosa IL, Neto NAL, Voeks R. 2012. Animals for the gods: magical and religious faunal use and trade in Brazil. Hum Ecol 40: 751-780. DOI: 10.1007/s10745-012-9516-1.

Alves RRN. 2012. Relationships between fauna and people and the role of ethnozoology in animal conservation. Ethnobiol Conserv 1: 1-69. DOI: 10.15451/ec2012-8-1.2-1-69.

Anwar D. 2018. Kamus lengkap Bahasa Indonesia. Penerbit Surabaya, Surabaya. [Indonesian]

BAPPENAS. 2012. Laporan Akhir Kajian Tahun 2012 Peran Masyarakat Adat Dalam Perumusan Kebijakan Publik, Jakarta. [Indonesian]

Bonifacio KM, Schiavetti A, Freire EMX. 2016. Fauna used by rural communities surrounding the protected area of Chapada do Araripe Brazil. J Ethnobiol Ethnomed 12:41. DOI: 10.1186/s13002-016-0115$\mathrm{X}$

BPS Kabupaten Poso. 2016. Kabupaten Poso dalam angka. Poso. 35p. [Indonesian]

CITES. 2019. CITES appendices I, II and III. http://checklist.cites.org/eng/app/appendices.php

Cotton CM. 1996. Ethnobotany : principles and applications. John Willey \& Sons, UK.
Drumond MA, Guimaraes AQ, Silva RHPD. 2015. The role of local knowledge and traditional extraction practices in the management of giant earthworms in Brazil. PLoS One 10 (4): 1-19. DOI : 10.1371/journal.pone.0123913.

Fahlevi Z, Azhar Al, Sayuti A, Isa M, Adam M, Alfian H. 2017. Blood chemistry of local swamp buffaloes (Bubalus bubalis) of Aceh. Jurnal Medika Veterinaria 11 (1): 66-70. DOI : DOI: 10.21157//j.med.vet..vl lil.4065. [Indonesian]

Farida MY, Jumari, Muhammad F. 2014. Etnozoologi suku anak dalam (SAD) kampung kebun Duren desa Lantak Seribu kecamatan Renah Pamenang kabupaten Merangin provinsi Jambi. Jurnal Biologi 3 (1): 29-39. [Indonesian]

Holmes G, Smith TA, Ward C. 2018. Fantastic beasts and why to conserve them : animal, magic and biodiversity conservation. Oryx. 52 (2): 231-239. DOI: 10.1017/S003060531700059X.

Hunn, ES. 2011.Ethnozoology. In: Anderson EN, Pearsall D., Hunn E., Turner N (eds) Ethnobiology. John Willey \& Sons Inc., New Jersey.

Ismail R. 2019. Ritual kematian dalam agama asli Toraja "Aluk to dolo" (Studi atas upacara kematian rambu solok). Religi 15 (1): 87-106. [Indonesian]

IUCN. 2019. The International Union For Conservation of Nature's Red List of Threatened Species. http://www.iucnredlist.org.

Khaeruddin I. 2019. The case of the German technical cooperation in supporting sustainable resources management in Lore Lindu Biosphere Reserve Central Sulawesi Indonesia. IOP Conf. Ser.: Earth Environ Sci 298 012029. 1-5. DOI: 10.1088/17551315/298/1/012029.

Kholis N. 2017. Identifikasi seni budaya benuansa keagamaan di Palu dan Poso Sulawesi Tengah. Jurnal "Al-Qalam" 23 (2): 359-369. [Indonesian]

Kusumaninrum EN, Supriatna J, Abinawanto, Bowolaksono A. 2018. Short Communication : Ethnozoology-The perception of Tobelo Dalam tribal community in Saolat Village, East Halmahera, Indonesia towards cuscus (Phalangeridae). Biodiversitas 19 (6) : 2140-2146.

Mashuri. 2011. Konsep Pelestarian Pusaka Saujana di Kawasan Lembah Bada. Mektek 13 (1): 23-30. [Indonesian]

Ministry of Environment and Forestry of Indonesia. 2014. The Fifth National Report of Indonesia The Convention on Biological Diversity, Jakarta. [Indonesian]

Munawaroh E, Purwanto Y, Prasetyo HS, Suryanto J, Ajiningrum PS. 2013. Aspek biofisik dan potensi cagar biosfer Lore Lindu. In: Purwanto Y, Walujo EB, Suryanto J, dan Munawaroh E (eds.). Strategi Adaptasi Pengelolaan Sumber Daya Alam Hayati Masyarakat Lokal Di Cagar Biosfer Lore Lindu. LIPI, Bogor. [Indonesian]

P.106. 2018. Peraturan Menteri Lingkungan Hidup dan Kehutanan Tentang Perubahan Atas Peraturan menteri Lingkungan Hidup Dan Kehutanan Nomor P.106/MENLHK/SETJEN/KUM.1/12/2018 Tentang Perubahan Kedua Atas Peraturan Menteri Lingkungan Hidup dan Kehutanan Nomor P.20/MENLHK/SETJEN/KUM.1/6/2018 Tentang Jenis Tumbuhan dan Satwa Yang Dilindungi (Menteri Lingkungan Hidup dan Kehutanan RI : Jakarta) pp1-30 http://ksdae.menlhk.go.id/assets/news/peraturan/P.20_Jenis_TSL.pdf. [Indonesian]

Permana CE. 2010.Kearifan Lokal Masyarakat Baduy Dalam Mitigasi Bencana. Wedatama Widya Sastra Press, Jakarta. [Indonesian]

Pilatus, Kartikawati SM, Anwari MS. 2017. Etnozoologi suku Dayak Kanayant di desa Babane Kabupaten Bengkayang. Jurnal Hutan Lestari 5 (3): 858-867. [Indonesian]

Pusat Data dan Statitistik Pendidikan dan Kebudayaan. 2016. Analisis Kearifan Lokal ditinjau Dari Keragaman Budaya. KEMENDIKBUD RI, Jakarta. [Indonesian]

Ramadiana, Anwari MS, Yani A. 2018. Etnozoologi untuk ritual adat dan mistis masyarakat Dayak Ella di desa sungai Labuk kecamatan Ella Hilir kabupaten Melawi. Jurnal Hutan Lestari 6 (3): 630-636. [Indonesian]

Rim. 2014. Pesona kain Kulit Kayu Nusantara : Menelusuri Jejak Peradaban Masa Lalu Sebagai Media Penguatan Jati Diri dan karakter Bangsa. Museum Sulawesi Tengah, Palu. [Indonesian]

Rintelen KV, Arida E, and Hauser C. 2017. A review of Biodiversity Related Issues And Challenges In Megadiverse Indonesia And Other Southeast Asian Countries. Research Ideas and Outcomes 3: e20860. DOI: 10.3897///rio.3.e20860.

Sartini, Effendhy S. 2012. Mitos-mitos situs sakral Alami dan Fungsinya Bagi Pengembangan Etika Lingkungan. Fakultas Filsafat, UGM, Yogyakarta. [Indonesian] 
Sukma AP, Anwari MS, Ardian H. 2019. Etnozoologi untuk ritual adat dan mistis masyarakat Melayu desa Naga Betung kecamatan Boyan Tanjung kabupaten Kapuas Hulu. Jurnal Hutan Lestari. 7 (2):916-922. [Indonesian]

Suryanto J, Munawaroh E, Ajiningrum PS. 2013. Studi aspek sosial ekonomi dan budaya masyarakat Pekurehua dan Toro di zona penyangga dan area transisi cagar biosfer Lore Lindu. Purwanto Y, Walujo EB, Suryanto J, Munawaroh E (eds.). Strategi Adaptasi
Pengelolaan Sumber Daya Alam Hayati Masyarakat Lokal Di Cagar Biosfer Lore Lindu. LIPI, Bogor. [Indonesian]

Verma AK, Prasad SB, Rongpi T, Arjun J. 2014. Traditional healing with animals (Zootherapy) By the major ethnic group of Karbi Anglong district of Assam, India. Intl J. Pharma Pharmaceut Sci 6 (8): 593600.

Yenmis M, Ayaz D, Tok CV. 2019. Ethnozoology: A Review. Acta Biologica Turcica 32 (1): 33-36. 